УДК: 339.138:[338.46:37.018-027.541

JEL I 210

(C) Романюк Н.B., 2021

n.romanyuk@chnu.edu.ua

Чернівецький національний університет імені Юрія Федьковича, Чернівиі

\title{
МОНІТОРИНГ МІЖНАРОДНИХ ЧИННИКІВ ТРАНСФОРМАЦІЇ РЕГІОНАЛЬНОЇ ОСВІТНЬОЇ МЕРЕЖІ ТА РЕГІОНАЛЬНИХ РИНКІВ ОСВІТНІХ ПОСЛУГ
}

Проведено моніторинг міжнародних чинників трансформаиії регіональної освітньої мережі та регіональних ринків освітніх послуг, який передбачає визначення групи міжнародних чинників таких, як глобалізація освіти, географічна трансформація та зростання обсягу світового ринку освітніх послуг, активна маркетингова політика провайдерів освітніх послуг, підвищена мобільність споживачів освітніх послуг, поява загальносвітових освітніх мереж, децентталізаиї витрат на вищу освіту, формування регіонами багатьох краӥн власних стратегій підвищення привабливості для залучення іноземних споживачів, зростання важливості регіональної освітньої та інновачійноі політики, глобальні ризики, які змінюють умови життя регіональної спільноти, задають нові контури конструювання освітніх мереж, провокують витіснення регіональних провайдерів освітніх послуг глобальними.

Ключові слова: глобалізація, інтеграџія, глокалізаџія, регіональна освітня мережа, інтернаціоналізація, регіоналізація освіти, глобальні ризики .

Постановка проблеми. Експерти компанії BCG [1] сучасні умови називають епохою постійних трансформацій, яка супроводжується безпрецедентними зрушеннями та збуренням практично в усіх галузях промисловості та на всіх ринках. Глобалізація, технологічні інновації, зміна регуляторних актів, соціально-демографічні виклики, зміна поколінь споживачів та інші фактори ставлять під сумнів усталені бізнес-моделі та практики, вимагають від організацій, компаній, регіонів, країн постійної трансформації. Тому головна вимога до регіональної освітньої мережі це наявність оптимальної моделі взаємодії учасників, у якій раціонально узгоджені чинники зовнішнього середовища та сформовані механізми швидкого реагування на безперервні зміни.

Аналіз останніх досліджень і публікацій. Глобалізацію як чинник трансформації освітніх систем розглядали Н. Авшенюк, О. Чабала, Т. Носуліч, І. Утюж, О. Хомеріки, Н. Константюк , М. Терованесов, Д.Берн, Б. Ліск та К. Брідж, Дж. Кнайт, П. Скотт, К. Чжиан, Г.Фрідман. На регіональному рівні ці проблеми є предметом уваги I. Заблодської [2], І. Сторонянської [3], І. Крупенної [4], О. Коломицевої [5] та інших. Учені одностайні у тому, що «глобалізація докорінно перетворює соціальну дійсність (спотворює цільові установки розвитку держав, змінює традиційні способи і технології виконання завдань, підвищує активність формування глобальної монокультури на основі єдиного інтересу обраних держав, породжує транснаціональні корпорації, які використовують глобальні умови господарювання винятково у власних інтересах)» [6]. Є. Неборський наділяє глобалізацію функціями тригера (англ. trigger спусковий пристрій), який підсилює такі процеси: зростання конкуренції; комерціалізацію наукової та освітньої діяльності; зміна контурів ринку праці; випробування ідентичністю; зростання підзвітності перед ключовими стейкхолдерами [7]. Інтеграція забезпечує взаємопов'язаність і взаємозалежність між суб'єктам регіональної освітньої мережі, «більш високий рівень взаємодії, гармонізацію основних характеристик суб’єктів ринку освітніх послуг, стирає кордони між освітніми системами» [8].

Формування цілей статті. Метою статті $є$ проведення моніторингу міжнародних чинників трансформації регіональної освітньої мережі та регіональних ринків освітніх послуг.

Виклад основного матеріалу дослідження. Глобалізацію освіти розуміють як «якісно новий процес створення всесвітньої єдиної уніфікованої системи, при якій стираються відмітності між освітніми системами, які входять у неї» [9], як «процес усе більшого пристосування системи навчання до запитів глобальної ринкової економіки» [10]. Глобалізацію в освіті, в першу чергу, пов'язують 3 підвищенням мобільності студентів, з можливістю отримати знання в іншій країні, з появою загальносвітових освітніх мереж, 3 розвитком цифрових технологій навчання, онлайносвіти, AR- i VR-технологій, нейрокомунікаційних технологій тощо. I. Утюж провела грунтовне дослідження глобалізації в освітній сфері, іiі основних напрямків, осмислення й аналіз усіх можливих позитивних і негативних рис, наслідків їх реалізації в Україні. Учена закцентувала увагу на тому, що розглядати «глобалізацію у сфері освіти доцільно через такі напрямки як інтернаціоналізація, інформатизація, інтеграція, вестернізація або їх поєднання, зорієнтовані на піднесення престижу національної освіти шляхом підвищення якості послуг, що надаються, i підвищення рівня підготовки людського капіталу до 
рівня світової конкурентоспроможності або перевершує його, які допомагають закладам своєчасно або навіть заздалегідь відповідати на існуючі та нові вимоги інформаційного суспільства та знаннєвої економіки, забезпечуючи тим лідируюче положення державі на світовій арені» $[11$, c.64].

Інтернаціоналізація в освіті, за Дж. Найт, - це процес інтеграції міжнародного, міжкультурного, глобального виміру в навчальні та дослідницькі функції, а також у функції адміністрування освітніх закладів [12]. Лідерство на міжнародному ринку знань дозволяе країнам зміцнювати свій економічний та політичний вплив (3 кінця 40-х років XX століття провідні світові держави почали розглядати міжнародні освітні обміни і програми як частину своєї зовнішньої політики, поставивши їх за важливістю в один ряд 3 військовою та економічною допомогою іншим країнам, адже через випускників можна посилювати свій політичний, мовний та культурний вплив). Надання освітніх послуг вищої та середньої освіти, мовні курси, додаткова професійна освіта, стажування $є$ однією з найбільш доходних експортних галузей. За оцінками експертів, інвестиції у виробництво приносять дохід $14-16 \%$, в науку $-200-600 \%$, а в підготовку, перепідготовку та підвищення кваліфікації фахівців і керівників - не менше 800\%, в окремих випадках - 4000-5000\% [13].

Тривалий час процес інтернаціоналізації освіти слідував за економічною інтеграцією, однак сьогодні зовнішня політика та інтеграційні стратегії розвитку зарубіжних країн та їх регіонів базуються на випереджаючому розвитку сфери освіти (табл.1) та науки. Спектр стратегій, які застосовують провідні світові університети 3 метою інтернаціоналізації, досить великий: програми подвійних дипломів, активні обміни викладачами i студентами, запровадження перспективних освітніх програм і модулів, стипендії та гранти для підтримки іноземних студентів, присутність на великих міжнародних освітніх платформах, розвиток систем заходів щодо адаптації зарубіжних студентів, активна робота 3 рекрутинговими агентствами в зарубіжних країнах тощо.

Таблиия 1

\section{Інтернаціоналізація у стратегіях розвитку регіональних освітніх мереж зарубіжних країн}

\begin{tabular}{|c|c|c|c|}
\hline Складові & Фінляндія & Великобританія & Китай \\
\hline Стратегї̈ & $\begin{array}{c}\text { зміцнення власної } \\
\text { конкурентоспроможності в } \\
\text { галузі вищої освіти і } \\
\text { створення можливості } \\
\text { виходу на міжнародний } \\
\text { освітній ринок } \\
\end{array}$ & $\begin{array}{c}\text { позиціонування власного } \\
\text { провідного положення на } \\
\text { міжнародному освітньому } \\
\text { ринку }\end{array}$ & $\begin{array}{c}\text { створення в країні великих } \\
\text { університетів, які } \\
\text { відповідають усім світовим } \\
\text { показникам }\end{array}$ \\
\hline \multirow{2}{*}{$\begin{array}{l}\text { Напрямки } \\
\text { діяльності }\end{array}$} & $\begin{array}{c}\text { створення міжнародного } \\
\text { співтовариства вищої освіти }\end{array}$ & $\begin{array}{c}\text { розвиток стратегій } \\
\text { маркетингу і комунікацій } \\
\text { для підтримки зростання } \\
\text { попиту на послуги освіти }\end{array}$ & $\begin{array}{c}\text { розширення впливу і } \\
\text { поліпшення репутації } \\
\text { китайських університетів }\end{array}$ \\
\hline & $\begin{array}{c}\text { розвиток експорту } \\
\text { експертизи }\end{array}$ & $\begin{array}{c}\text { диверсифікація } \\
\text { міжнародних ринків } \\
\text { освітніх послуг }\end{array}$ & $\begin{array}{c}\text { вивчення інформації про } \\
\text { передові наукові досягнення і } \\
\text { успішний досвід управління у } \\
\text { сфері освіти різних країн }\end{array}$ \\
\hline $\begin{array}{c}\text { Пріоритети } \\
\text { інституційного } \\
\text { розвитку } \\
\end{array}$ & $\begin{array}{c}\text { удосконалення якості та } \\
\text { привабливості системи } \\
\text { вищої освіти } \\
\end{array}$ & $\begin{array}{c}\text { забезпечення якості умов } \\
\text { перебування іноземних } \\
\text { студентів у країні }\end{array}$ & $\begin{array}{c}\text { зміцнення міжнародного } \\
\text { співробітництва та обмінів у } \\
\text { галузі освіти }\end{array}$ \\
\hline $\begin{array}{l}\text { Пріоритети } \\
\text { міжнародної } \\
\text { діяльності }\end{array}$ & $\begin{array}{c}\text { підтримка полікультурного } \\
\text { суспільства }\end{array}$ & $\begin{array}{l}\text { встановлення міцних } \\
\text { партнерських зв'язків }\end{array}$ & $\begin{array}{c}\text { інтернаціоналізація } \\
\text { навчальних планів і створення } \\
\text { спільних освітніх програм }\end{array}$ \\
\hline
\end{tabular}

*Джерело: [14].

Процеси інтернаціоналізації в освіті $\mathrm{CC}$ забезпечує ряд міжнародних організацій: Європейська асоціація університетів (European University Association, EUA), Європейська академічна університетська мережа (European Academic University Network, ACEAH), Мережа університетів столиць Європи (Network of Universities from the Capitals of Europe), Мережа
УТРЕХТ (the Utrecht Network), Європейська мережева інформаційна система (European Network Information System), Свропейська асоціація міжнародної освіти (European Association of International Education, EAIE), Центральноєвропейська мережа ініціативних університетів (Central European Initiative University Network), Європейська асоціація 
закладів вищої освіти (European Association of Institutions in Higher Education, EURASHE) та інші [14].

Обсяг світового ринку освітніх послуг постійно зростає, змінюється його структура (сьогодні на користь он-лайн формату), географічна трансформація освітнього ринку, з'являються нетрадиційні провайдери та надавачі, зміщуються акценти освітнього продукту та переваги споживачів, розширюються програми і проекти за напрямками транснаціонального навчання, 3'являються нові експортери освітніх послуг, змінюються напрямки та наповнюваність потоків академічної мобільності. Світова організація торгівлі у 2008 році оцінювала місткість світового ринку освіти у $\approx \$ 90-100$ млрд. Проте, на думку ряду експертів, до 2030 року обсяг ринку може зрости і досягти \$600-800 млрд. [15]. Обсяг сегмента вищої освіти, за прогнозами експертів компанії JL, до 2020 року складе $\$ 70$ млрд [16]. Згідно 3 даними дослідження міжнародного інформаційного агентства East-West Digital News [17], обсяг світового ринку дистанційної освіти становив у 2017 році \$5 трлн 3 перспективами зростання в декілька разів, а за оцінками експертів EdCrunc, світові витрати на освіту і підготовку кадрів, до 2030 року досягнуть, як мінімум $\$ 10$ трлн. За звітом OECP «Education at a Glance 2018» [18], загальні державні витрати на початкову та вищу освіту у відсотках від загальних державних витрат для країн ОЕСР становлять у середньому $11 \%$. Важливість участі регіонів у фінансуванні освіти засвідчують тренди децентралізації витрат на вищу освіту (початковий, середній та післявузівський не вищий рівень) - 57\% кінцевих коштів управляються регіональними та місцевими органами влади. На відміну від цього, витрати на третинному рівні більш централізовані, лише $17 \%$ кінцевих державних коштів отримують 3 регіонального та місцевого рівня.

Потоки міжнародної академічної мобільності вимірюються декількома мільйонами осіб у рік: якщо у 2001 році число іноземних студентів, які переїжджали в інші країни для здобуття вищої освіти, складало 2,1 млн. осіб, то у 2015 році ця цифра склала - 4,6 млн., а у 2017 р. - 5,3 млн. в 2017 р [19]. Щорічне зростання чисельності складає приблизно 300000 іноземних студентів або на 6\% порівняно 3 попереднім роком. На початку XXI століття конкуренція країн-експортерів освіти змінила рейтинги постачальників освітніх послуг (табл.2). Основними країнами-реципієнтами іноземної освітньої мобільності $є$ такі економічно розвинені країни: США, Великобританія, Австралія, Німеччина, Франція, РФ. Ключові країнипостачальники іноземних студентів - Китай, Індія, Німеччина, Південна Корея, Малайзія, Франція, В'єтнам, Саудівська Аравія, США [21].

Таблиия 2

Міжнародна мобільність студентів у ключових приймаючих країнах і країнах походження, 2008-2016 рр., 2018 р. (прогноз)

\begin{tabular}{|l|c|c|c|c|c|c|c|c|c|c|}
\hline & $\mathbf{2 0 0 6} \mathbf{p}$ & $\mathbf{2 0 0 8} \mathbf{p}$ & $\mathbf{2 0 1 0} \mathbf{p}$ & $\mathbf{2 0 1 2} \mathbf{p}$ & $\mathbf{2 0 1 3} \mathbf{p}$ & $\mathbf{2 0 1 4} \mathbf{p}$ & $\mathbf{2 0 1 5} \mathbf{p}$ & $\mathbf{2 0 1 6} \mathbf{p}$ & $\begin{array}{c}\mathbf{2 0 1 6} \mathbf{p} \\
\text { до } \\
\mathbf{2 0 0 6} \mathbf{~ p . ~}\end{array}$ & $\begin{array}{c}\mathbf{2 0 1 8} \\
\text { прогно3 }\end{array}$ \\
\hline \multicolumn{8}{|c|}{ Країни-реципіснти } \\
\hline США & 584719 & 624474 & 684807 & 740482 & 784427 & 842384 & 907251 & 971417 & $166,1 \%$ & 1040121 \\
\hline Великобританія & 330078 & 341791 & 389958 & 427686 & 416693 & 428724 & 430687 & 432001 & $130,9 \%$ & 433319 \\
\hline Австралія & 184710 & 230635 & 271231 & 249588 & 249868 & 266048 & 294438 & 335512 & $181,6 \%$ & 382316 \\
\hline Німеччина & 189450 & 177852 & 181249 & 192853 & 204644 & 218848 & 235858 & 251542 & $132,8 \%$ & 268269 \\
\hline Франція & 247510 & 243436 & 259935 & 271399 & 228639 & 235123 & 239409 & 245349 & $99,1 \%$ & 251436 \\
\hline Росія & 77438 & 136791 & 129690 & 173627 & 173627 & 213347 & 213347 & 243752 & $314,8 \%$ & 278490 \\
\hline \multicolumn{8}{|c|}{ Країни-донори } \\
\hline Китай & 419247 & 473742 & 579795 & 705057 & 721358 & 769898 & 819059 & 865337 & $206,4 \%$ & 914230 \\
\hline Індія & 147608 & 186033 & 210649 & 191779 & 190358 & 215611 & 256636 & 301406 & $204,2 \%$ & 353986 \\
\hline Німеччина & 84200 & 105600 & 127600 & 139200 & 135000 & 138800 & 115900 & 144900 & $172,1 \%$ & 181156 \\
\hline Південна Корея & 104509 & 117533 & 126187 & 121198 & 113799 & 110024 & 107762 & 104992 & $100,5 \%$ & 102293 \\
\hline Нігерія & 35131 & 41299 & 52148 & 57298 & 63565 & 79296 & 92476 & 95731 & $272,5 \%$ & 99101 \\
\hline Франція & 53229 & 46978 & 57407 & 64196 & 76576 & 82057 & 86690 & 90543 & $170,1 \%$ & 94567 \\
\hline
\end{tabular}

*Джерело: [20]

За даними 2018/2019 р., поряд зі США (освіта п’ята за значимістю стаття експорту американської економіки), Великобританією, Австралією (освітні послуги $є$ третьою за важливістю статтею експорту послуг, на частку якої припадає $12 \%$ його обсягу), на ринку експортів освітніх послуг «набирають силу» помітні та сильні гравці: Нідерланди, Малайзія, Туреччина, Японія, Південна Корея, Росія, Китай та інші. Якщо у 2016 році йшлося, в основному, про потік міжнародної мобільності студентів з Китаю до США, Великобританії, Австралії та Японії, то за даними Міністерства закордонних справ Китаю 
(MOFA) [22], у 2018 році в Китаї: навчалося понад 470000 іноземців (на 35\% більше ніж у 2014 р.); загальна частка іноземних студентів, які шукають вищу освіту в Китаї, зросла на $13 \%$ за останні 10 років; приблизно 30 відсотків учнів були зараховані в початкову або середню школи; понад $50 \%$ іноземних студентів 3 Китаю приїжджають із сусідніх країн (Південна Корея, Таїланд і Росія). Китай залучає більше іноземних студентів, ніж будьяка інша азіатська держава, ВНЗ країни завойовують симпатії навіть у тих країнах, з якими колись були напружені відносини (В'єтнам). А в Індонезії та Малайзії китайські вузи можуть дозволити собі будівництво кампусів за $\$ 60$ млн., після дворічного навчання в яких іноземці переїжджають до Китаю i набагато швидше адаптуються до нового середовища. Можна зробити припущення, що коронавірус 2020 року може змінити ситуацію і потоки мобільності знову будуть переважно одновекторними - міграцію студентів з Китаю в інші країни.

Згідно 3 державною ініціативою Global 30, Японія до 2020 року планує залучити в свої університети, як мінімум, 300000 іноземних студентів. Японська система освіти вважається найліпшою в Азії, вона охоплює близько 780 вузів, 53 яких входять до топ-100 найліпших університетів світу за рейтингом QS World University Rankings 2019. Крім підвищення якості освіти та наукових досліджень, Японія вживає додаткових заходів для залучення іноземних студентів - збільшення кількості англомовних програм, стипендії, програми адаптації та підтримки для іноземців, спрощений процес зарахування.

Європейські держави залишаються привабливими центрами освіти для величезного числа іноземних студентів. Серед європейських країн статус інтернаціонального науково-дослідного регіону з високим ступенем привабливості в плані наукового обміну та залучення іноземних студентів набула Німеччина. Запорука іï успіху - інтеграція німецької системи науки і вищої освіти в міжнародну спільноту; відкритість та реальна свобода наукових досліджень, значні інвестиції у вищу освіту. Число іноземних студентів у німецьких закладах вищої освіти в 2017 році зросло на п'ять відсотків, склавши 359000 осіб (12,8\% всіх учнів). Кількість німецьких студентів за кордоном (Австрія, Нідерланди, Великобританія, Швейцарія та США) становить у цілому 137.700. Німеччина $\epsilon$ привабливим майданчиком для вчених з усього світу: 2007 року кількість зарубіжних наукових співробітників в німецьких ВНЗ зросла на 84\%; у 2016 році в Німеччині нараховувалося 46000 зарубіжних учених (більшість - математики та інженери). Розвиваються також позауніверситетські наукові організації. Так, за кількістю зарубіжних співробітників лідирує Товариство ім. Макса Планка (46\%). Кількість іноземних студентів в Україні в 2019/2020 н.р. у вищих навчальних закладах складає понад 63820 осіб. У першу десятку за кількістю іноземних студентів в Україні входять Індія (14860), Марокко (6046), Азербайджан (4858), Туркменістан (4541), Нігерія, Грузія, Йорданія, Сгипет, Туреччина та Узбекистан.

Формою інтернаціоналізації $\epsilon$ транснаціональна освіта, яка охоплює пропозицію усіх видів програм вищої освіти або комплекси освітніх курсів, або освітні послуги, і за якою здобувачі освіти знаходяться в країні, відмітній від тієї, в якій базуються освітні установи [23]. Транснаціональна освіта перетворюється на великий бізнес, який використовує франчайзинг, філіальні, регіональні, локальні, офшорні кампуси, дистанційне навчання, програми співробітництва тощо (табл.3).

Німецькі програми транснаціонального співробітництва (TNE) відповідно до класифікації Міжнародної програми і мобільності постачальників 2019p.

\begin{tabular}{|l|l|c|c|c|c|}
\hline \multicolumn{2}{|c|}{ ТNВ Тур } & \multicolumn{2}{c|}{ Курси } & \multicolumn{2}{c|}{ Студенти } \\
\cline { 3 - 6 } & & Кількість & Частка, \% & Кількість & Частка, \% \\
\hline \multirow{2}{*}{ Самостійні } & Франчайзингові програми & 8 & $2,8 \%$ & 427 & $1,3 \%$ \\
\cline { 2 - 6 } & Філіальний або регіональний кампус & 13 & $4,6 \%$ & 845 & $2,6 \%$ \\
\hline \multirow{2}{*}{ Спільні } & Програми співробітництва & 115 & $40,6 \%$ & 7800 & $23,7 \%$ \\
\cline { 2 - 6 } & Об’єднаний університет & 147 & $51,9 \%$ & 23873 & $72,5 \%$ \\
\hline \multicolumn{2}{|c|}{ Усього } & $\mathbf{2 8 3}$ & & $\mathbf{3 2 9 4 5}$ & \\
\hline
\end{tabular}

*Джерело: [20]

Ринок знань, особливо в сегменті освітніх послуг, який довгий час базувався на інтернаціоналізації, змінює свої тренди: активне просування освітніх послуг національним споживачам або клієнтам 3 країн, які культурно близькі; зростання викладання національними 
мовами 3 одночасним зниженням частки англомовних програм (хоча деякі країни, наприклад Нідерланди та Японія, збільшують кількість анголомовних програм) тощо.

Інтернаціоналізація передбачає створення єдиної системи освіти для різних країн, сумісність різних форм і систем навчання, мобільність освітнього середовища та його суб'єктів. Зовнішня інтернаціоналізація охоплює різноспрямовані (в країну, регіон, 3 країни, регіону) викладацькі та студентські потоки, створення стратегічних альянсів, розробку програм 3 отримання подвійного диплома тощо. Внутрішня інтернаціоналізація спрямована на залучення більшого числа іноземних студентів фахівців, створення для них комфортних умов адаптації, перебування. Результатом інтернаціоналізації може бути: експорт освітніх послуг (Великобританія, Фінляндія, Польща, Чехія); розширення можливостей країни за рахунок імпорту освітніх послуг (Китай, Катар, OAE); зниження можливостей країни через виїзд студентів на навчання без наміру повернутися в країну (Україна, Молдова).

Для залучення іноземних студентів у вищі навчальні заклади Франції, в країні створено потужну інфраструктуру, в якій провідна роль належить державному агентству CampusFrance його 136 зарубіжних представництв відіграють активну роль у розвитку студентської та викладацької мобільності, сприяння подвійних і спільних програм навчання [24]. У Франції широко використовуються власні стипендіальні програми підтримки іноземних студентів [25], а також кошти європейських фондів для розвитку докторських i спільних магістерських програм 3 іншими європейськими інститутами. Агентство французької освіти за кордоном (AEFE) - це державний оператор 3 питань французької освіти за кордоном [26]. Агентство має власну службу сприяння розвитку мережі (SADR), яка надає підтримку державним або приватним інвесторам, які бажають вкласти кошти в певний освітній проект. Посольства Франції виконують функцію координаторів розвитку мережі SADR на місцях - розробляють локальні плани розвитку французької освіти, які враховують місцеві умови, проводять аналіз попиту і пропозиції на освітні послуги, вживають заходів для злагодженого і контрольованого розвитку навчальних закладів при збереженні високої якості викладання. Позитивний баланс економіки Франції в сегменті підготовки іноземних студентів у розмірі $€ 1,65$ млрд. Витрати іноземних студентів досягають €4,65 млрд. євро, у тому числі: «€3250 млн. - на щоденні споживчі витрати; €563 млн. - на оплату за навчання; €466 млн. - відвідування Франції родичами іноземних студентів; €364 млн. - доходи національних авіакомпаній» [27].

Україні зі своєю національною системою освіти, стандартами та класифікаторами професій вийти на міжнародний ринок освітніх послуг, де конкурують вже усталені системи країн Європейського Співтовариства, США, Японії, Австралії, нарощують свій потенціал країни Центральної та Східної Свропи, вкрай складно, але можливо та потрібно. Регіони України повинні готувати свої пакетні пропозиції (освітні програми, кампуси, інфраструктуру, послуги, освітнє та громадське середовище) для іноземних студентів, адже попит вітчизняних споживачів падає або переливається в сусідні країни, які швидше вийшли на міжнародний ринок знань.

В експортну «гонку» освітніх послуг вступають регіони країн, які формують власні стратегії підвищення освітньої, поселенської та міграційної привабливості, адже іноземні студенти створюють додаткові джерела надходжень до місцевих бюджетів, розширюють підприємницьке поле для жителів, активізують регіональний споживчий ринок та ринок нерухомості, поліпшують вікову структуру регіону, розширюють коло потенційних лояльних зарубіжних партнерів транслюючи культуру, традиції, досягнення країни та регіону перебування тощо. Автор теорії «м'якої сили», Д. Най у монографії цитує колишнього держсекретаря Сполучених Штатів Америки Коела Пауелла: «Я думаю, що немає нічого більш цінного активу для нашої країни, ніж дружба $з$ майбутніми світовими лідерами, які отримали тут свою освіту [28].

Стратегічно орієнтовані регіони розробляють регіональні програми залучення іноземних студентів, які передбачають удосконалення освітньої інфраструктури, облаштування комфортних кампусів, коворкінгових зон, культурних дестинацій, сучасних бібліотек, залучення членів громади до таких програм (оренда житла, проживання в родині, мовне опікунство), стимулювання місцевих підприємств для прийому іноземних студентів на стажування, залучення державних стипендіальних програм i грантів, упровадження нових форм навчання, інноваційних технологій та освітніх програм, включеність регіону в спільні дослідницькі проекти, співпраця з інвесторами та індустріальними партнерами, підвищення інноваційності регіону, розвиток системи інформаційно-комунікаційних, правових, консультаційних, побутових сервісів тощо.

Дослідники відзначають ще один цікавий тренд - «глобальний найм», який зумовлений глобальною конкуренцією фахівців і за фахівців та робота у форматі «home offise» («піжамний працівник»). У 2013 р кількість людей, які 
працюють віддалено зросла до 1,2 млрд. осіб. У США близько 47\% працівників зайняті дистанційно протягом половини кожного тижня, а $10 \%$ - хоча б раз на тиждень. Найперспективнішими країнами для організації даного режиму роботи є Японія та Китай. За дослідженням Ipsos / Reuters, більше половини зайнятого населення в Індії вважають за ліпше працювати дома, в Індонезії - 34\%, в Мексиці - 30\%, трохи менше в Аргентині, Південній Африці i Туреччині. В Свропі дистанційна зайнятість менш популярна - лише $10 \%$ зайнятих в Угорщині, Німеччині, Швеції, Франції, Італії та Канаді. Компанія Cisco має близько 10 тис. співробітників по всьому світу, найнятих у системі «home offise». Дослідники компаніï Global Workplace Analytics підрахували, що середній американський бізнес може заощадити близько \$11 тис. щорічно на віддалених співробітників за рахунок менших витрат на обладнання та оренду офісу, його прибирання, а також воду і їжу для співробітників. Великі компанії, такі як American Express або Aetna, в середньому економлять \$15-78 млн на рік. A Apple i Google орієнтуються на створення комфортних дорогих офісів, сучасної побутової та житлової інфраструктури для своїх співробітників, що займають цілі вулиці і квартали в Силіконовій долині. У компанії IBM у свій час $40 \% 3386$ тис. співробітників по всьому світу працювали у форматі «home offise», але з 2017 року ця практика була припинена.

Інтеграція України в СС зумовила появу ще кількох явищ, які тісно пов'язані 3 процесом глобалізації і прямо стосуються європейського освітнього простору - регіоналізація та європеїзація. М. Слонімская, досліджуючи мережеві форми організації економіки, зробила висновок, що «в умовах глобалізації збільшується число регіоналістів, які підтримують ідею про те, що в міжнародній конкуренції велику роль відіграють регіональні кластери і мережі» [29] - М.Портер,
М.Сторпер, А. Куах, регіональної інтеграції, формування регіональних утворень. Прихильники цієї гіпотези приходять до думки про те, що з розвитком процесів глобалізації знову зростає важливість регіональної політики. «Регіоналізація освіти - принцип розвитку світової освіти, який визначається загальносвітовими тенденціями соціокультурного розвитку суспільства, визнанням унікальності національних і регіональних варіантів культур, їх єдності та цілісності» [30]. Регіоналізація спрямована використання місцевого потенціалу освітньої системи, місцевих акторів ринку освітніх послуг, громади, місцевих традицій, надбань історичного розвитку, геополітичного положення, природних ресурсів та інших іманентних властивостей певної території. Л.Сфремова пропонує регіоналізацію освіти розглядати на різних рівнях: «на макрорівні вона виражається в прагненні локальних цивілізацій захистити себе від впливу ззовні; на мезорівні - проявляється в інтеграції окремих територій, що входять до складу різних держав сучасного світу; на мікрорівні - процеси регіоналізації розгортаються всередині національних держав» [31]. Як зазначає Р. Стернберг, «глобалізація і нова регіоналізація являють собою дві сторони однієї і тієї ж монети» [33]. Органічне та динамічне поєднання локальних і глобальних потоків і ресурсів, інтеграцію локальних і глобальних сил для розвитку POM передбачає глокалізація (global + local = glocal). Регіональна освітня мережа має кластерні ознаки і може описуватися глокальною моделлю, де «потоки фінансового та фізичного капіталу мають глобальну мобільність, потоки соціального капіталу прив'язані до ландшафту території (формування мережевих зв'язків багато в чому залежить від місцевого бізнесклімату), а потоки людського капіталу мають змішану мобільністю» [32]. При трансформації регіональної освітньої мережі глокалізація проявляється у поєднанні локальних і глобальних процесів (рис.2):

\begin{tabular}{|c|c|c|}
\hline 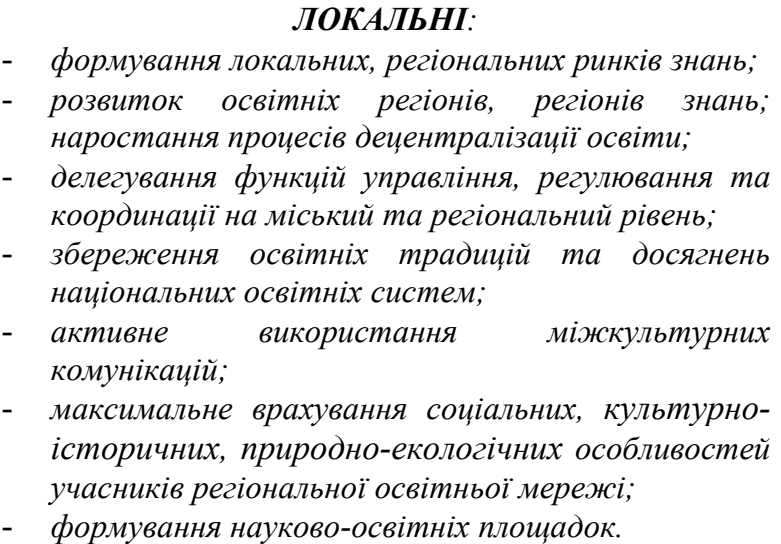 & 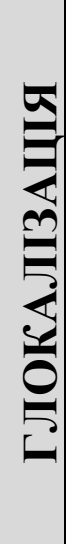 & $\begin{array}{l}\text { Гбов'язання дотримуватися умов міжнародних } \\
\text { огуляторів світового освітнього простору } \\
\text { ЮНЕСКО); } \\
\text { обов'язання дотримуватися умов єдиного } \\
\text { вропейського освітнього простору вищео̆освіти } \\
\text { Болонський прочес); }\end{array}$ \\
\hline
\end{tabular}

Рис. 2. Глокалізація як чинник трансформації регіональної освітньої мережі 
Глокалізація демонструє переваги органічної, інтегрованої, позитивної взаємодії глобалізації та регіоналізації, оскільки глокалізація ресурсообороту, мережева відкритість, мережеві зв'язки та інститути колаборації дозволяють регіональній освітній мережі обрати спеціалізацію, залучити зовнішні глобальні ресурси (мережі та комунікації), поєднати основних акторів мережевої взаємодії, створити адекватну систему формування професійних компетенції, сформувати унікальний освітній продукт. У підсумку території, де з'являються кластери, успішно залучають глобальних інвесторів, що допомагає їм потрапити в глобальні мережі i вписатися в ситуацію глобальної конкуренції [33]. «Сучасні освітні лідери повинні розвивати глокальну грамотність в дев'яти конкретних галузях знань: політична грамотність, економічна грамотність, культурна грамотність, моральна грамотність, педагогічна грамотність, інформаційна грамотність, організаційна грамотність, духовна i релігійна грамотність і світська грамотність» [34], що дозволить їм підвищити власне КРІ.

Проведений аналіз міжнародних чинників дозволив також виділити негативний вплив глобалізації на освітні системи - глобальні ризики (англ. Global Risks), які зафіксовані в У Доповіді Всесвітнього економічного форуму «Global Risks Report» 2018 року [35]. Глобальні ризики потенційно здійснюють прямий та непрямий вплив на трансформацію та стратегії розвитку освітніх систем. С. Неборський [7] зазначає, що у першому випадку проблеми розв'язуються через формування відкритих освітніх мереж, участь у дослідних проектах або освітніх програмах, у другому - глобальні ризики змінюють умови життя суспільства, задають нові контури конструювання освітніх мереж, провокують глибоку соціальну нестабільність, провокують витіснення регіональних провайдерів освітніх послуг глобальними.

Висновки. Виходячи 3 даного дослідження, можна стверджувати, що вплив чинника глобалізації на формування та трансформацію РОМ буде полягати у поступовому переході від національної та регіональної компоненти до загальносвітових проблем, у посиленні інтернаціоналізації освітніх програм і наукових досліджень, у підвищенні мобільності студентів, працівників, населення, капіталів і бізнесу, у розвитку форм залучення абітурієнтів, у зміні політики та алгоритмів найму персоналу, форматів та умов праці, у зміні формату трансляції та отримання знань на всіх освітніх рівнях, розробку регіональних програм стимулювання до навчання протягом життя, в посиленні ролі університетів як центрів міжнародного співробітництва регіону, у трансформації форм взаємодії та партнерства усіх суб’єктів регіону.

\section{Список літератури}

1. Hemerling J., Dosik D., Rizvi Sh. A leader's guide to "always-on" transformation. BCG Perspectives. November 9, 2015.

2. 2.Заблодська I. В., Плетньов М. В., Заблодська Д. В. Результати моніторингу ринку освітніх послуг: регіональний аспект. Ефективна економіка: електрон. наук. фахове вид. 2017. URL: http://www.economy.nayka. com.ua

3. Сторонянська I. 3., Беновська Л. Я. Проблеми функціонування освітньої мережі та шляхи іiі консолідації. Регіональна економіка. 2017. № 3. С. 5564.

4. Немцева I. А. Організаційна культура в системі стратегічного управління вищими навчальними закладами України: монографія. Чернівці: Чернів. нац. ун-т, 2012. $256 \mathrm{c.}$

5. Васильченко Л.С., Коломицева О.В., Управління регіональними освітніми мережами: маркетинговий підхід. Збірник наукових пращџь Донещького державного університету Управління «Проблеми та перспективи забезпечення стабільного соиіально-економічного розвитку». Серія «Економіка». 2019. Том XX, Випуск 311. С.141-149.

6. Галайда В. А. Глобализация и регулирование сетевой экономики в условия х взаимодействия национальных экономических систем. Управление. 2013. № 2 (2). C. 27-37.
7. Неборский Е. В. Глобальные риски как вызов развитию современных университетов. Интернетжурнал «Мир науки». 2017. T. 5. № 6. URL: https://mirnauki.com/PDF/95PDMN617.pdf

8. Хомерікі О. А. Інтернаціоналізація і інтеграція як напрямки глобалізації освіти: процеси синтезу і диференціації. Актуальні проблеми соиіології, психології, педагогіки. 2012. № 16. С. 76-84.

9. Кичева И. В. Обогащение педагогической терминологии в 90-е годы XX века. Пятигорск: Изд-во ПГЛУ, 2004. 404 с.

10. Щелкунов М. Д. Образование в эпоху глобализации. Вестник экономики, права и социологии. 2008. № 2. С. 95-100.

11. Утюж И. Г. Глобализация в системе высшего образования. Гуманітарний вісник ЗДІА. 2011. № 47. С. $51-65$.

12. Knight J. Updated definition of internationalisation. International Higher Education. The Boston College Center for International High Education, USA. 2003. No. 33 Fall.

P. 2-3.

URL: http://www.bc.edu/content/dam/files/ research_sites/cihe/ pdf/IHEpdfs/ihe33.pdf

13. Денисон Э. Исследование различий в темпах экономического роста. Москва: Прогресс, 1971. 645 с.

14. Мигович I. В. Інституційний аспект трансформації національної системи вищої освіти 
Словацької республіки (на матеріалі роботи університету імені Коменського в Братиславі). Вісник Черкаського університету. 2018. № 12. С. 62-74.

15. Bhandari R., Belyavina R., Gutierrez R. Student and the internationalisation of higher education: national policies and strategies from six world regions. Institute of International Education. New York, 2011.

16. Trends \& Inzichten. URL: https://www.jll.nl/nl/trends-inzichten?cbla15df-4322-4fef8244-d8f74da97d2d

17. East-West Digital News. URL: https://www.ewdn.com/

18. OECD. Education at a glance 2019: OECD indicators, OECD publishing. 2019. URL: https://doi.org/10.1787/f8d7880d-en

19. A world on the move: trends in global student mobility. Institute of International Education (IIE). New York, 2018. URL: https:/www.iie.org/ Research-andInsights/Publications/A-World-on-the-Move

20. Wissenschaft weltoffen 2019.

URL: http://www.wissenschaftweltoffen.de/ wwo2019/index html?lang=en

21. UNESCO Institute for Statistics. 2015. URL: http://www.uis.unesco.org

22. Міністерство закордонних справ Китаю (MOFA). URL: https://www.fmprc.gov.cn/mfa eng/

23. Code of good practice in the provision of transnational services. Strasbourg, 31 January, 2002. URL: http://www.coe.int/t/dg4/highereducation/ recognition/code $\% 20$ of $\% 20$ good $\% 20$ practiceEN.asp

24. Campus France Vous Accompagne. URL: http://www.campusfrance.org

25. Тагирова Ш. В. Высшее образование Франции: состояние и перспективы. Партнерство Франциии и России: интернационализация образования, науки, экономики / под общ. ред. Г.А. Красновой, Е. В. Пономаренко. Москва: Дело, 2015. С. 11-23.

26. Développer l'enseignement français à l'étranger: un nouvel

élan.
URL: https://www.diplomatie.gouv.fr/IMG/pdf/developp er_1_enseignement_francais_a_1_etranger__ossier_de_presse_cle02ed67.pdf

27. Россия и Франция в мировом образовательном пространстве: аналит. докл. / под общ. ред. И. Н. Барцица. Москва: Изд. дом «Дело» РАНХиГС, 2017. $400 \mathrm{c}$.

28. Nye Joseph S. Jr. Soft power and higher education. The Internet and the University. Devlin Maureen, Larson Richard, Meyerson Joel. Educause: 2005. P. 11-14.

29. Слонимская М. А. Сетевые формы организации экономики: монография / науч. ред. А. Е. Дайнеко; Нац. акад. наук Беларуси, Ин-т экономики. Минск: Беларуская навука, 2018. 278 с.

30. Шабанова М. М., Алиева Р. Р. Регионализация образования как важный фактор сбалансированного социально-экономического развития региона. Гуманизация образования. 2010. № 1. С. 68-73.

31. Ефремова Л. И. Регионализация и глобализация образовательного пространства СНГ: социальнофилософский анализ: автореф. дис. на соиск. ученой степени канд. филос. наук. Москва, 2010. 22 с.

32. Катуков Д. Д., Малыгин В. Е., Смородинская Н. В. Институциональная среда глобализированной экономики: развитие сетевых взаимодействий / под ред. Н. В. Смородинской. Москва: ИЭ РАН, 2012. 45 с.

33. Sternberg R. Innovation networks and regional development - evidence from the European Regional Innovation Survey (ERIS): theoretical concepts, methodological approach, empirical basis and introduction to the theme issue. European Planning Studies. 2000. Vol. 8. No. 4. P. 389-407.

34. Brooks J. S., Normore A. H. Educational leadership and globalization: literacy for a glocal perspective. Educational Policy. 2010-01-01. Vol. 24. Iss. 1. P. 52-82.

35. The Global Risks Report 2018. 13th Edition. Geneva: World Economic Forum, 2018. 80 p.

\section{References:}

1. Hemerling J., Dosik D., Rizvi Sh. (2015). A leader's guide to "always-on" transformation. BCG Perspectives. November 9.

2. Zablodskaya I.V., Pletnev M.V., Zablodskaya D.V. (2017), Results of monitoring the educational services market: a regional aspect. Effective economy: electron. sciences. professional look. No. 12.URL: http://www.economy.nayka. com.ua

3. Storonyanska I. Z., Benovska L. Ya. (2017). Problems of the function of publicity and paths and consolidation. Regional economy. No. 3. P. 55-64.

4. Nemtseva I. A. (2012). Organizational culture in the system of strategic management of higher educational institutions of Ukraine: monograph. Chernivtsi: Chernov. nat. un-t, $256 \mathrm{p}$.

5. Vasilchenko L.S., Kolomitseva A.V. (2019). Management of regional educational networks: a marketing approach. Collection of scientific papers of Donetsk State University of Management "Problems and prospects of ensuring stable socio-economic development." Series "Economics". Vol. XX, Issue 311. P.141-149.

6. Galayda V.A. (2013). Globalization and regulation of the networked economy in the context of interaction of national economic systems. Control. No. 2 (2). P. 27-37.

7. Neborskiy E.V. (2017). Global risks as a challenge to the development of modern universities. Internet magazine "World of Science". Vol. 5.No.6 URL: https://mir-nauki.com/PDF/95PDMN617.pdf

8. Homeriki O.A. (2012). Internationalization and integration as directions of globalization of education: processes of synthesis and differentiation. Problems of sociology, psychology, pedagogy. № 16. pp. 76-84.

9. Kicheva I.V. (2004). Enrichment of pedagogical terminology in the 90s of the XX century. Pyatigorsk: PSLU Publishing House, $404 \mathrm{p}$.

10. Shchelkunov M. D. (2008) Education in the era of globalization. Bulletin of Economics, Law and Sociology. No. 2. P. 95-100.

11. Utyuzh I. G. (2011). Globalization in the system of higher education. Humanitarian visnik. No. 47, pp. 51-65. 
12. Knight J. Updated definition of internationalisation. International Higher Education. The Boston College Center for International High Education, USA. 2003. No. 33 Fall.

P. 2-3.

URL: http:/www.bc.edu/content/dam/files/ research_sites/cihe/pdf/IHEpdfs/ihe33.pdf

13. Denison E. (1971). Research of Differences in the Rates of Economic Growth. Moscow: Progress, 645 p.

14. Migovich I.V. (2018)/ Institutional aspect of the transformation of the national system of higher education of the Slovak Republic (based on the work of the Comenius University in Bratislava). Bulletin of Cherkasy University. № 12. pp. 62-74.

15. Bhandari R., Belyavina R., Gutierrez R. Student and the internationalisation of higher education: national policies and strategies from six world regions. Institute of International Education. New York, 2011.

16. Trends \& Inzichten. URL: https://www.jll.nl/nl/trends-inzichten?cbla15df-4322-4fef8244-d8f74da97d2d

17. East-West Digital News. URL: https://www.ewdn.com/

18. OECD. Education at a glance 2019: OECD indicators, OECD publishing. 2019 URL: https://doi.org/10.1787/f8d7880d-en

19. A world on the move: trends in global student mobility. Institute of International Education (IIE). New York, 2018. URL: https:/www.iie.org/ Research-andInsights/Publications/A-World-on-the-Move

20. Wissenschaft weltoffen

2019.

URL: http://www.wissenschaftweltoffen.de/ wwo2019/index html?lang=en

21. UNESCO Institute for Statistics. 2015. URL: http://www.uis.unesco.org

22. Ministry of Foreign Affairs of China (MOFA). URL: https://www.fmprc.gov.cn/mfa eng/

23. Code of good practice in the provision of transnational services. Strasbourg, 31 January, 2002. URL: http://www.coe.int/t/dg4/highereducation/ recognition $/$ code $\% 20$ of $\% 20 \operatorname{good} \% 20$ practiceEN.asp

24. Campus France Vous Accompagne. URL: http://www.campusfrance.org
25. Tagirova Sh. V. (2015). Higher education in France: state and prospects. Partnership between France and Russia: internationalization of education, science, economics / under total. ed. G. A. Krasnova, E. V. Ponomarenko. Moscow: Delo, pp. 11-23.

26. Développer l'enseignement français à l'étranger : un nouvel élan. URL: https://www.diplomatie.gouv.fr/IMG/pdf/developp er 1 enseignement francais a 1 etranger _dossier_de_presse_cle02ed67.pdf

27. Russia and France in the global educational space: analyt. report / under total. ed. I. N. Bartsitsa. Moscow: Publishing house. House "Delo" RANEPA, 2017. 400 p.

28. Nye Joseph S. Jr. Soft power and higher education. The Internet and the University. Devlin Maureen, Larson Richard, Meyerson Joel. Educause: 2005. P. 11-14.

29. Slonimskaya M.A.( 2018). Network forms of organization of the economy: monograph. Minsk: Belaruskaya Navuka, 278 p. (in Rus.).

30. Shabanova M. M., Alieva R. R. (2010). Regionalization of education as an important factor of balanced socio-economic development of the region. Humanization of education. No. 1. P. 68-73.

31. Efremova L.I. (2010). Regionalization and globalization of the educational space of the CIS: sociophilosophical analysis: author. dis. for a job. scientific degree of Cand. Philos. sciences. Moscow, 22 p. (in Rus.).

32. Katukov D. D., Smorodinskaya N. V. (2012). Institutional environment of the globalized economy: development of network interactions. Moscow: IE RAS, 45 p. (in Rus.).

33. Sternberg R. Innovation networks and regional development - evidence from the European Regional Innovation Survey (ERIS): theoretical concepts, methodological approach, empirical basis and introduction to the theme issue. European Planning Studies. 2000. Vol. 8. No. 4. P. 389-407.

34. Brooks J. S., Normore A. H. Educational leadership and globalization: literacy for a glocal perspective. Educational Policy. 2010-01-01. Vol. 24. Iss. 1. P. 52-82.

35. The Global Risks Report 2018. 13th Edition. Geneva: World Economic Forum, 2018. 80 p.

\section{Аннотация}

Надежда Романюк

\section{МОНИТОРИНГ МЕЖДУНАРОДНЫХ ФАКТОРОВ ТРАНСФОРМАЦИИ РЕГИОНАЛЬНОЙ ОБРАЗОВАТЕЛЬНОЙ СЕТИ И РЕГИОНАЛЬНЫХ РЫНКОВ ОБРАЗОВАТЕЛЬНЫХ УСЛУГ}

Проведен мониторинг международных факторов трансформации региональной образовательной сети и региональных рынков образовательных услуг, который предполагает определение группь международных факторов таких, как глобализация образования, географическая трансформация и рост объема мирового рынка образовательных услуг, активная маркетинговая политика провайдеров образовательных услуг, повышенная мобильность потребителей образовательных услуг, появление общемировых образовательных сетей, децентрализачии расходов на высшее образование, формирование регионами многих стран собственных стратегий повышения привлекательности для привлечения иностранных потребителей, рост важности региональной образовательной и инновационной политики, глобальные риски, которые изменяют условия жизни регионального сообщества, задают новые контуры конструирования образовательных сетей, провоцируют вытеснение региональных провайдеров образовательных услуг глобальными.

Ключевые слова: глобализачия, интеграџия, глокализация, региональная образовательная сеть, интернационализация, регионализация образования, глобальные риски. 


\section{Summary \\ MONITORING OF INTERNATIONAL FACTORS OF TRANSFORMATION OF THE REGIONAL EDUCATIONAL NETWORK AND REGIONAL MARKETS OF EDUCATIONAL SERVICES}

Nadiia Romaniuk

The article monitors the international factors of transformation of the regional educational network and regional markets for educational services, which involves the identification of a group of international factors such as the globalization of education, geographic transformation and growth in the volume of the world market for educational services, active marketing policy of educational service providers, increased mobility of consumers of educational services., the emergence of global educational networks, the decentralization of spending on higher education, the formation by regions of many countries of their own strategies to increase attractiveness to attract foreign consumers, the growing importance of regional educational and innovation policies, global risks that change the living conditions of the regional community, set new contours for the design of educational networks, provoke the crowding out of regional providers of educational services by global ones.

It is concluded that it is extremely difficult for Ukraine and its regions to enter the international market of educational services, where the already established systems of the USA, EU countries, East and Southeast Asia compete, countries of Central and Eastern Europe are increasing their potential, but it is possible and expedient. The regions of Ukraine should prepare their own package offers for foreign students, because the demand of domestic consumers falls or spills over to neighboring countries that have previously entered the international knowledge market. 